7. Лавренчук О. В. Багдасарова І. В., Король Л. В., Мигаль Л. Я. Біохімічні предиктори розвитку хронічної хвороби нирок у дітей, реконвалесцентів гострого пошкодження нирок I.В. Запорожский медииинский журнал. 2021. Том 23. № 1 (124). С. 65-71.

8. Lopez-Giacoman S., Madero M. Biomarkers in chronic kidney disease, from kidney function to kidney damage. World Journal of Nephrology. 2015. Vol. 4. Issue 1. P. 57-73.

9. Watters S. T., Sung J., Skoog S. J. Endoscopic treatment for vesicoureteral reflux: how important is technique? Journal of Pediatric Urology. 2013. Vol. 9 (6 Pt B). P. 1192-1197.

DOI https://doi.org/10.30525/978-9934-26-113-8-10

\title{
ЧИННИКИ РИЗИКУ РОЗВИТКУ ПОСТМЕНОПАУЗАЛЬНОГО ОСТЕОПОРОЗУ
}

\author{
Пилипчук I. C. \\ кандидат медичних наук, \\ дочент кафедри акушерства та гінекологіі \\ Львівський національний медичний університет \\ імені Данила Галищького \\ Флуд В. В. \\ кандидат медичних наук, \\ асистент кафедри акушерства та гінекологї \\ Львівський національний медичний університет \\ імені Данила Галицького \\ Петришин 3. Я. \\ асистент кафедри акушерства та гінекології \\ Львівський національний медичний університет \\ імені Данила Галиџького \\ м. Львів, Украӥна
}

Остеопороз (лат. osteoporosis) - це метаболічне захворювання скелета, що характеризується прогресуючим зниженням кісткової маси в одиниці об єму кістки відносно нормального показника в осіб відповідної статі та віку, порушенням мікроархітектоніки кісткової тканини зі збільшенням крихкості та ризику їх переломів від мінімальної травми 
або без неї. Постменопаузальний остеопороз становить 85\% в структурі первинного остеопорозу і може розвиватися в третини жінок у період пери- і постменопаузи.

За перші 5 років постменопаузи втрата кісткової тканини у жінок може становити 30-35\% від усієї кісткової маси. Втрата кісткової маси відбувається у дві фази: швидка фаза та повільна. Швидка фаза спостерігається в перші 5 років постменопаузи (щорічно втрата становить близько 3-5\% кісткової тканини, в основному за рахунок структур хребта). Повільна фаза - починається із 55 років (щорічна втрата $0,5-1 \%$ кісткової тканини залежно від ділянки скелета). Швидкість втрати кісткової маси різна в жінок, тому розрізняють три групи: «швидко» (становить 25\% - належать більшість молодих жінок після двобічної оваріоектомії), «нормально» і «повільно» втрачають кісткову масу.

Остеопороз - поліетіологічне системне захворювання скелету, що характеризується патологічним зменшенням маси кісткової тканини (резорбційна дія остеокластів переважає над секреторною активністю остеобластів) та виникненням в подальшому підвищеної ламкості кісток. До чинників ризику остеопорозу, відносять:

- стать (жіноча);

- вік (старший);

- етнічну приналежність (біла раса, азіатське походження);

- сімейний анамнез (переломи або остеопороз) - відомо понад 30 генів асоційованих з розвитком остеопорозу;

- пізне менархе (після 16 років);

- ранню або передчасну менопаузу (до 40-45 років);

- довгу пременопаузальну аменорею (понад 1 рік);

- періоди аменореї та/або олігоменореї;

- непліддя (ановуляція);

- оваріектомію у молодому віці;

- більше трьох вагітностей і пологів у репродуктивному віці;

- тривалі періоди лактації;

- шкідливі звички - зловживання алкоголем, наркотичними засобами, тютюнопаління;

- недостатність вітаміну D;

- розлади харчування - низький рівень кальцію, фосфору, магнію, цинку, бору, заліза, фтору, вітамінів А, К, Е і С, надлишок соди, надлишок вживання білків;

- низька маса тіла;

- неактивний спосіб життя (фізична активність дозволяє підтримати та збільшити кісткову масу на 1-2\%);

- надмірна фізична активність;

- важкі метали (кадмій);

- зловживання газованими напоями (наявність фосфатної кислоти); 
- тривала імобілізація (правило «використовуй або втрачай»);

- супутня патологія (гіпогонадичні стани, гіпер- та гіпофункція щитоподібної залози, наднирникова недостатність, цукровий діабет 1 i 2 типу), захворювання шлунково-кишкового тракту, ревматологічні захворювання, захворювання нирок та ниркова недостатність, гематологічні захворювання (множинна мієлома, моноклональні гемопатії, лімфома, лейкемія, мастоцитоз, гемофілія, серповидноклітинна анемія, таласемія), ідіопатичний сколіоз, хвороба Паркінсона, деякі спадкові захворювання (синдром Марфана, гематохроматоз, гіпофосфатазія, глікогеном, гомоцистинурія, синдром Менкеса, бульозний епідермоліз, хвороба Гоше);

- застосування деяких медикаментів (глюкокортикоїди, антиконвульсанти, барбітурати, L-тироксин, метотрексат, інгібітори ароматази, антиметаболіти, антагоністи гонадотропін-рилізинг гормону, антикоагулянти, інгібітори протонової помпи, тіазолідиндіони, препарати літію) [1,2].

Протягом останніх років обгрунтовано провідну роль статевих гормонів, а саме естрогену в регуляції кісткового маси. Збільшення ризику розвитку остеопорозу і частоти переломів у жінок у клімактерії передусім пов'язано зі зниженням функції яєчників: відносний дефіцит естрогену, зниження щільності кісток (на 23\% щороку), що й призводить до розвитку остеопорозу. Настання постменопаузи негативно впливає на стан кісткового метаболізм, внаслідок цього у $25-40 \%$ жінок розвивається постменопаузний остеопороз. Остеопороз вражає від третини до половини всіх жінок у постменопаузний період. На даний час у світі його діагностовано приблизно у 200 млн. жінок [3]. Дефіцит естрогену призводить до зменшення інгібування остеокластів і зниження активності остеобластів, підвищення чутливості кісткових клітин до дії паратиреоїдного гормону (ПТГ), прорезорбтивних цитокінів (інтерлейкін-1, інтерлейкін-6, інтерлейкін-11, чинник некрозу пухлин $\alpha$ тощо), що сприяє прискоренню та відокремленню процесів кісткового ремоделювання [4]. Прямий ефект естрогену обумовлений впливом на специфічні рецептори остеокластів, за рахунок чого відбувається пригнічення ïx резорбтивної функції. Опосередкована дія естрогену на кістку реалізується за рахунок впливу на кальцієвий гомеостаз, яка здійснюється шляхом зменшення чутливості кісткової тканини до дії ПТГ, стимуляції синтезу кальцитоніну та кальцитріолу, забезпечуючи адекватну абсорбцію кальцію в кишківнику [5,6]. Отже, губчаста речовина кісткової тканини є своєрідним органом-мішенню для статевих гормонів [7]. Захисна дія естрогену на кістку різко знижується, зростає втрата кістками мінералів, у першу чергу кальцію, відбувається втрата цілої трабекули та трабекулярної мережі, зростає крихкість кісток, розвивається остеопенія та остеопороз [8]. Механізм розвитку вищенаведених змін під впливом зменшення концентрації естрогену 40 
залишається нез'ясованим. Існують дані, що свідчать про наявність рецепторів естрогену в остеобластах та остеокластах. Поряд із дефіцитом естрогену, патогенез остеопорозу включає й інші ланки (за участю вітаміну $\mathrm{D}_{3}$, ПТГ, кальцитоніну). Характерною особливістю остеопорозу $\epsilon$ переважне ураження трабекулярної кісткової тканини. У зв'язку з цим, найбільш уразливим $є$ хребет, що на 95\% складається з трабекулярної кістки, і дистальний відділ променевої кістки [9]. Системний остеопороз відносять до пізніх обмінно-ендокринних проявів постменопаузы. Сумарний ризик остеопоротичних переломів для жінок віком від 50 років складає $39,7 \%$ [10].

Отже, остеопороз - це медична, суспільна, соціальна та економічна проблема сьогодення. Це найбільш поширене захворювання опорнорухового апарату, яке займає 4 місце у світі як причина інвалідності та смертності серед неінфекційної патології, тому потребує подальшого дослідження та вивчення.

\section{Література:}

1. Болгова М.Ю. Остеопороз: (учеб.-метод. пособие). Астрахан. гос. мед. акад. Росздрава. Астрахань, 2010. 70 с.

2. Бугрим Т.В., Фуштей И.М. Постменопаузальный остеопороз. Запорож. мед. журнал. 2012. № 4. С. 5-8.

3. Odabasi E., Turan M., Tekbas F., Kutlu M. Evaluation of secondary causes that may lead to bone loss in women with osteoporosis: a retrospective study. Arch. Gynecol. Obstet. 2009. Vol. 279, № 6. P. 863-867.

4. Древаль А.В., Оноприенко Г.А., Шумский В.И. и др. Постменопаузальный остеопороз: новые подходы к диагностике и лечению. Альманах клин. медицины. 1998. № 1. С. 145-153.

5. Булгакова С. В., Давыдкин И. Л. Взаимосвязь факторов риска остеопороза и минеральной плотности костной ткани у женщин в постменопаузе. Терапевт. архив. 2009. № 1. С. 76-79.

6. Mehrotra R.N., Ranjan A., Lath R., Ratnam R. Postmenopausal osteoporosis: Our experience. Indian. J. Endocrinol. Metab. 2012. Vol. 16, suppl. 2. P. S421-S422.

7. Риггз Б.Л., Мелтон Л. Д. Остеопороз: Этиология, диагностика, лечение: пер. с англ. Санкт-Петербург, 2000. 558 с.

8. Казимирко В. К., Коваленко В. Н., Мальцев В. И. Остеопороз: патогенез, клиника, профилактика и лечение. Киев, 2006. 160 с.

9. Подзолкова Н.М., Кузнецова И.В., Никитина Т.И. Менопаузальный остеопороз: классификация остеопороза, диагностика остепороза, профилактика и лечение остеопороза, морфология и физиология нормальной кости. Москва, 2012. 63 с.

10. Пилипчук I.C., Пилипчук I.I. Остеопороз та якість життя жінки в XXI столітті. Люблін, 2020. С. 253-275. 